\section{EMBRYRIDDLE}

Aeronautical University

SCHOLARLY COMMONS
Journal of Aviation/Aerospace

Education \& Research

Volume 17

Number 2 JAAER Winter 2008

Article 5

Winter 2008

\title{
Pre-Testing as a Method of Conveying Learning Objectives
}

Wendy S. Beckman

Follow this and additional works at: https://commons.erau.edu/jaaer

\section{Scholarly Commons Citation}

Beckman, W. S. (2008). Pre-Testing as a Method of Conveying Learning Objectives. Journal of Aviation/ Aerospace Education \& Research, 17(2). https://doi.org/10.15394/jaaer.2008.1447

This Article is brought to you for free and open access by the Journals at Scholarly Commons. It has been accepted for inclusion in Journal of Aviation/Aerospace Education \& Research by an authorized administrator of Scholarly Commons. For more information, please contact commons@erau.edu. 


\title{
PRE-TESTING AS A METHOD OF CONVEYING LEARNING OBJECTIVES
}

\author{
Wendy S. Beckman
}

\begin{abstract}
Teaching methodologies involving student pre-testing have been used in K-12 education for a number of years. Although pre-testing has been conducted in some collegiate classrooms, there have been very few studies published regarding the effectiveness of the concept. This paper reports the results of a study in which one Introduction to Aerospace class was given a pre-test at the start of each unit of study, while a second class received a list of specific learning objectives at the start of each unit. The post-test unit test results of the two classes were then compared. The results of the study indicate that pre-testing may be a very effective means of communicating course expectations to students.
\end{abstract}

\section{Introduction}

During the last ten to fifteen years, $\mathrm{K}-12$ education has embraced and experienced success with the concept of student pre-testing. In that environment, pre-tests are typically used to determine if students have the prerequisite skills needed for the upcoming unit of instruction, or to what extent students have already achieved the objectives of the planned instruction (Linn \& Miller, 2005). While these functions are equally applicable in higher education, there are other benefits as well. In the collegiate environment, the pre-testing methodology has not been widely utilized, but from the literature available, the additional value of pretesting for college students seems to lie in; 1) clearly laying out the expectations of what students are to learn to do and 2) demonstrating the amount of learning that is taking place (Vocational Instructional Materials Lab, 1998).

A review of the literature on pre-testing in the collegiate environment reveals a limited number of publications, found in a variety of disparate disciplines. What is interesting is that each of these articles reported success in the classroom using pre-testing concepts, even though they were implemented in a variety of ways. Shepard $(2002$, p. 1091) found that assessing prior knowledge and experience not only improved her teaching, but also drew students into the habit of reflecting on their own knowledge. She states:

After all, what safer time to admit what you do not know than at the start of an instructional activity?
What better way to demonstrate to students that assessment (knowing what you know and what you do not know) helps learning?

In science education, Liggett-Fox (1997, p. 29) found that pre-testing can assist students in laying aside their previous misconceptions about a topic:

...too often we don't investigate what misconceptions our students have. Even if we find out what beliefs our students have, we assume that giving them the "correct" information will make them abandon their misconceptions and adopt the new information. We need to understand that students form misconceptions based on their experiences. As a result, our students do not have any motivation to give up their closely held beliefs because their misconceptions seem to work...

By having questions scored "incorrect" on a pre-test, she found that her students were more interested in finding out why they missed the question, leading them to consider the possibility that their basic premises were incorrect.

A chemistry professor (Ochs, 1998, p. 401 and 403) found that the benefit of pre-testing in his upper level course was to have students realize what they did not know about fundamental chemistry, which in turn made them more receptive to continued chemical education. He reported that: 
Having given such tests for three years now, I can report that the benefits exceeded expectations. Not only do most students now attend to fundamental chemical ideas, but also the entire approach to the course is much more positive... in previous years, without the pre-test, students were listless, and few took notes in the first day lecture. By contrast, after the quiz, the response to the first lecture was entirely different: the students were deadly silent, all took copious notes and they listened intently. A further benefit was that many overcame their timidity in asking even simple questions. This approach can make students aware of what they don't know and provide an impetus to deepen their understanding of basic concepts.

One theme that ran through the literature was the critical importance of being clear of the objectives of the course. The act of preparing pre-tests, whether for an entire course or a particular unit, acted as an impetus for faculty to become very clear in their own minds of the important objectives of the course. An education professor (Bemauer, 1998, p. 26) commented:

The decision to develop a measurement-driven method resulted from my growing awareness that instead of teaching the most important knowledge, skills, and attitudes that my students needed to attain, I had fallen victim to the trap of trying to "cover the material." I decided, therefore, that it was necessary, first, to identify critical learning goals, and then, based on these goals, to develop assessment items to guide my teaching, student learning, and the evaluation of student achievement.

Further findings to this effect was indicated by Stiggins (1994) who found that the most serious impediment to improving education was not the quality of either instruction or assessment, but rather the failure of instructors to identify clearly what were the most important objectives for learning. Angelo and Cross (1993, p. 8) put it simply: "Before faculty can assess how well their students are learning, they must identify and clarify what they are trying to teach." Additionally, given that most students will study primarily what they perceive they will be tested on, it is imperative that faculty ask the right questions in assessment situations (Resnick and Resnick, 1992). Consequently, it is critical to first identify an achievable set of the most important curricular goals, and then to ensure that objectives, instruction, and assessment items each align with these goals (Bernauer, 1998).

\section{Statement of the Problem}

As a collegiate faculty member, this author has previously shied away from pre-testing as it seemed to define too narrowly the expectations of what students were expected to learn from a course. In some sense, leaving the course objectives broad lends to the course the possibility of students learning more than just what an instructor determines is valuable for them to know. But on the other hand, if a course instructor does not clearly define what a student should be able to do when they leave a course, is it fair to expect the students to understand what is expected? This realization a number of years ago led to the development of very specific learning objectives for each course I teach, which are much more detailed than the broad course objectives outlined in my syllabi. More than a "study guide" for a particular test, these objectives are distributed at the beginning of each unit, and students are encouraged to track their progress in mastering the objectives as we move through the unit.

In spite of repeated exhortations on the use of these objectives for students to track their progress in each unit, that quintessential student question at the end of each unit, "What's going to be on the test?" still occurred with alarming regularity. It seemed that no matter how it was insisted upon that the objectives which had been distributed actually were, "What's going to be on the test", students were dissatisfied with that answer. This phenomenon started the search to find a method to impress upon students what knowledge and abilities were expected of them at the end of each unit of study. As the literature above indicates, there have been successful applications of pre-testing in the collegiate environment, and it seemed possible that this method of sharing learning objectives might be useful to freshmen taking an Introduction to Aerospace course. Freshmen in particular are quite concerned about the expectations of the collegiate environment, and since they had probably been exposed to the pre-testing concept in the secondary educational environment, it seemed that this approach might be helpful in their adaptation to college expectations.

The purpose of this study was to determine which was more effective; distributing a list of specific learning objectives for each unit, or utilizing a pre-test for each unit which operationalized the learning objectives for the students. The unit post-tests for the class were developed from the learning objectives for the unit, and were not identical to the pre-tests. In Table 1, a short list of representative examples of both learning objectives and pretest questions from each section can be seen. 
Table 1

Comparison of Learning Objectives and Pre-Test Questions

\begin{tabular}{|c|c|}
\hline $\begin{array}{l}\text { Examples of Learning Objectives from } \\
\text { Each Unit }\end{array}$ & $\begin{array}{l}\text { Examples of Pre-test Questions from } \\
\text { Each Unit }\end{array}$ \\
\hline \multicolumn{2}{|l|}{ Unit One } \\
\hline $\begin{array}{l}\text { - Be able to discuss the contributions of the } \\
\text { following aviation pioneers....Octave Chanute, } \\
\text { Samuel Langley, Otto Lillienthal, Hiram } \\
\text { Maxim, etc. }\end{array}$ & $\begin{array}{l}\text { - Name the German engineer of the } 1890 \text { 's } \\
\text { who has been called the "father of glider } \\
\text { experiments". }\end{array}$ \\
\hline $\begin{array}{l}\text { Be able to discuss the impact airmail had on } \\
\text { the development of commercial aviation in the } \\
\text { United States }\end{array}$ & $\begin{array}{l}\text { - List three contributions the carriage of } \\
\text { airmail made to the furtherance of aviation in } \\
\text { the United States }\end{array}$ \\
\hline \multicolumn{2}{|l|}{ Unit Two } \\
\hline $\begin{array}{l}\text { Be able to discuss the three axes of an } \\
\text { aircraft and describe how movement occurs } \\
\text { around each of them }\end{array}$ & $\begin{array}{l}\text { - What is the movement about an aircraft's } \\
\text { longitudinal axis called? }\end{array}$ \\
\hline $\begin{array}{l}\text { - Be able to explain the principles of operation } \\
\text { of an aircraft's pitot-static system }\end{array}$ & $\begin{array}{l}\text { - The static ports on an aircraft provide } \\
\text { pressure to what instrument(s)? }\end{array}$ \\
\hline \multicolumn{2}{|l|}{ Unit Three } \\
\hline $\begin{array}{l}\text { - Be able to explain the purpose and } \\
\text { ramifications of the General Aviation } \\
\text { Revitalization Act of } 1994\end{array}$ & $\begin{array}{l}\text { - What were the stipulations of the General } \\
\text { Aviation Revitalization Act of } 1994 \text { ? }\end{array}$ \\
\hline $\begin{array}{l}\text { Be able to discuss the idea of Crew Resource } \\
\text { Management and why this concept is so } \\
\text { important to the aviation industry }\end{array}$ & $\begin{array}{l}\text { - Explain briefly what the concept of "Crew } \\
\text { Resource Management" (CRM) entails. }\end{array}$ \\
\hline
\end{tabular}

\section{Research Methodology}

Two sections of Introduction to Aerospace at Middle Tennessee State University (MTSU) during the spring 2006 semester were used to compare the effectiveness of the two methods. The first section, which was designated the "Pre-test class" comprised a population of 25 students, while the second section, which was designated the "Learning Objectives class" consisted of 32 students. The attrition rate for the Pre-test class was $4 \%$ (one student), and the attrition rate for the Learning Objectives class was $6.25 \%$ (two students). The test grades of these three students who withdrew before completion of the term were not considered in determining the effectiveness of either methodology. The demographics of the two classes were very similar, with the Pre-test class having a minority percentage of $4 \%$, a female percentage of $8 \%$, and $88 \%$ of the students classified as "freshmen". The Learning Objectives class had a minority percentage of $3 \%$, a female percentage of $9 \%$, and $91 \%$ of the students classified as "freshmen". For each student not classified as a "freshman", the reason for them taking the class when they had completed more than 30 college credit hours was that they had transferred into the Aerospace program from a different major.

The Introduction to Aerospace course is a freshman level class, designed as a survey of the aviation/aerospace industry. One unit of the class is dedicated to the history of aviation, one unit to the current state of the aviation industry including career exploration, and one unit to the development of basic aeronautical knowledge. Thus, the course is divided into three separate units, and after each unit there is a post-test.

In order to compare the effectiveness of the two methods of instruction, the Learning Objectives class was given a list of specific learning objectives at the beginning of each unit. The Pre-test class was administered a pre-test, on which each question corresponded to a particular learning objective. These pre-tests were scored, recorded, and returned to the student. Besides this difference, the two sections of the class were given identical treatments, i.e., 
they were taught in the same manner, and by the same instructor. The results of students in both sections on the unit post-tests were subsequently recorded, for use in determining which method of instruction was most effective. The null hypothesis for the study was: There is no difference between the class of Introduction to Aerospace students being given a pre-test prior to each unit of study and the class of Introduction to Aerospace students being given a list of unit learning objectives prior to each unit of study.

\section{Data Analysis}

The data from each of the two classes were first analyzed at a macroscopic level, using a per student cumulative test average over all three course unit tests. As can be seen by Figure 1 and Figure 2, the student test results were approximately normally distributed in each case.
Figure 1

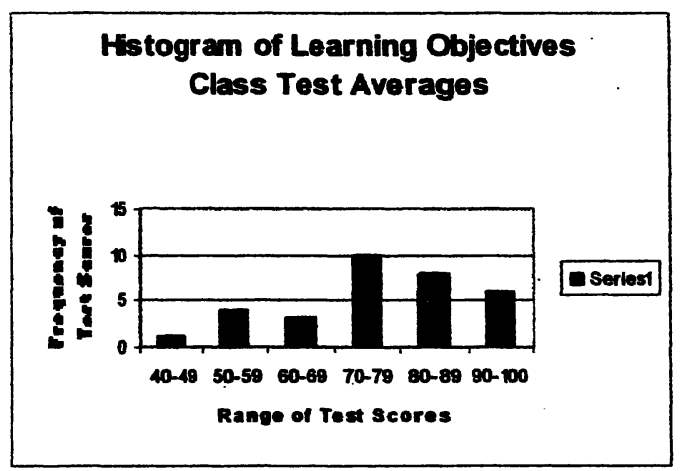

Figure 2

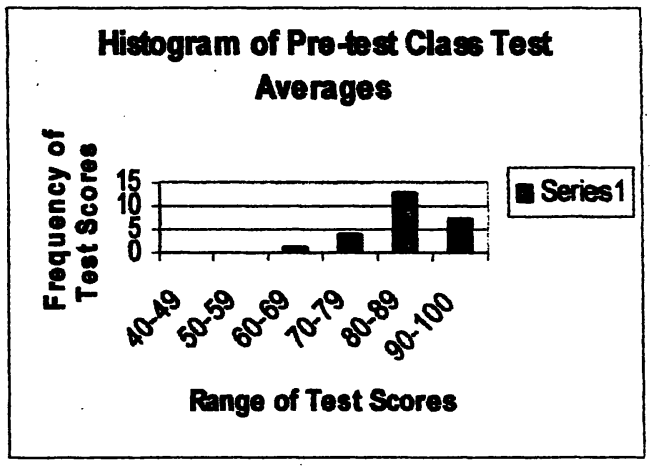

As can be seen in Table 2, the variance for the Pretesting class is quite different than the variance for the Learning Objectives class. This being the case, a two sample $t$-test assuming unequal variances was used to determine the $t$ values at the .05 level of significance. This test revealed a significant difference between the overall test averages of the two classes, $t(55)=3.4272, p<0.05$. The results of this t-test may also be seen in Table 2 .

Table 2

Comparison of the Two Classes' Overall Test Averages
\begin{tabular}{|l|l|l|}
\hline $\begin{array}{l}\text { t-Test: Two-Sample Assuming Unequal } \\
\text { Variances }\end{array}$ & & \\
\hline & $\begin{array}{l}\text { Pre-test } \\
\text { Class }\end{array}$ & $\begin{array}{l}\text { Learning } \\
\text { Objectives Class }\end{array}$ \\
\hline Mean & 85.9067 & 75.9583 \\
\hline Variance & 65.6715 & 185.5681 \\
\hline Observations & 25 & 32 \\
\hline Hypothesized Mean Difference & 0 & \\
\hline Df & 55 & \\
\hline T Stat & 3.4272 & \\
\hline T Critical two-tail & 2.0053 & \\
\hline
\end{tabular}


Next, a comparison of student performance on each of the three individual unit tests was conducted, to determine if the pre-testing procedure was impactive in each particular unit. The descriptive statistics and the results of the two sample $t$-test assuming unequal variances may be seen in Table 3, Table 4, and Table 5. In Table 3, it can be seen that there was a significant difference between the test one averages of the two classes, $t(55)=3.5439, p<0.05$. In
Table 4 it can be seen that there was a significant difference between the test two averages of the two classes, $t(55)=$ $3.17011, p<0.05$. In Table 5 it can be seen that there was a significant difference between the test three averages of the two classes, $\mathrm{t}(55)=2.0416, \mathrm{p}<0.05$, although this was the smallest difference of the three tests.

Table 3

Comparison of Test One Averages

\begin{tabular}{|l|l|l|}
\hline $\begin{array}{l}\mathrm{t}-\text { Test: Two-Sample Assuming Unequal } \\
\text { Variances }\end{array}$ & & \\
\hline & Pre-test Class & $\begin{array}{l}\text { Learning } \\
\text { Objectives Class }\end{array}$ \\
\hline Mean & 87.88 & 76.5625 \\
\hline Variance & 196.5266 & 381.8024 \\
\hline Observations & 25 & 32 \\
\hline Hypothesized Mean Difference & 0 & \\
\hline Df & 55 & \\
\hline T Stat & 2.5439 & \\
\hline T Critical two-tail & 2.0053 & \\
\hline
\end{tabular}

Table 4

Comparison of Test Two Averages

\begin{tabular}{|l|l|l|}
\hline $\begin{array}{l}\text { t-Test: Two-Sample Assuming Unequal } \\
\text { Variances }\end{array}$ & & \\
\hline & Pre-test Class & $\begin{array}{l}\text { Learning } \\
\text { Objectives Class }\end{array}$ \\
\hline Mean & 80.76 & 68.8438 \\
\hline Variance & 114.2733 & 305.8780 \\
\hline Observations & 25 & 32 \\
\hline Hypothesized Mean Difference & 0 & \\
\hline Df & 55 & \\
\hline T Stat & 3.17011 & \\
\hline T Critical two-tail & 2.0053 & \\
\hline
\end{tabular}


Table 5

Comparison of Test Three Averages
\begin{tabular}{|l|l|l|}
\hline $\begin{array}{l}\text { t-Test: Two-Sample Assuming Unequal } \\
\text { Variances }\end{array}$ & & \\
\hline & Pre-test Class & $\begin{array}{l}\text { Learning } \\
\text { Objectives Class }\end{array}$ \\
\hline Mean & 89.08 & 82.4688 \\
\hline Variance & 125.5767 & 174.8377 \\
\hline Observations & 25 & 32 \\
\hline Hypothesized Mean Difference & 0 & \\
\hline Df & 55 & \\
\hline T Stat & 2.0416 & \\
\hline T Critical two-tail & 2.0053 & \\
\hline
\end{tabular}

A statistical comparison of the two classes' final exam scores was also performed (the final exam was cumulative and composed of variations of questions from the three unit tests). The descriptive statistics for both classes' performance on the final exam can be seen in Table
6. It can be seen that there was a significant difference between the final exam averages of the two classes, $t(55)=$ 2.7450, $\mathrm{p}<0.05$.

Table 6

Comparison of Final Exam Scores
\begin{tabular}{|l|l|l|}
\hline $\begin{array}{l}\mathrm{t}-\text { Test: Two-Sample Assuming Unequal } \\
\text { Variances }\end{array}$ & & \\
\hline & Pre-test Class & $\begin{array}{l}\text { Learning } \\
\text { Objectives Class }\end{array}$ \\
\hline Mean & 88.8 & 78.875 \\
\hline Variance & 82.33333 & 312.9516 \\
\hline Observations & 25 & 32 \\
\hline Hypothesized Mean Difference & 0 & \\
\hline Df & 55 & \\
\hline T Stat & 2.7450 & \\
\hline T Critical two-tail & 2.0053 & \\
\hline
\end{tabular}

It was also interesting to compare the amount of gain in scores from pre-test to post-test for the Pre-test class, which of course, was not possible for the Learning Objectives class. As can be seen in Table 7, the class had an overall pre-test mean of 27.23 points out of 100 , as compared to an overall post-test mean of 85.91 points out of 100 , representing a gain of around 58 points. If performance on each of the individual unit pre-tests and post-tests are compared, an average gain of approximately 70 points is seen on the first test, with average gains of 60 points and 45 points seen on the second and third tests, respectively.

An analysis of pre-test versus post-test scores was evaluated for the Pre-test class, to verify that there was indeed significant impact from the instruction students received. At $\mathrm{t}(48)=16.2416, \mathrm{p}<0.05$, there was a significant difference between the pre-test and post-test scores, as seen in Table 7. 
Table 7

Comparison of Pre-test Class Pre-test and Post-test Results
\begin{tabular}{|l|l|l|}
\hline $\begin{array}{l}\text { t-Test: Two-Sample Assuming Unequal } \\
\text { Variances }\end{array}$ & & \\
\hline & $\begin{array}{l}\text { Post-test } \\
\text { Scores }\end{array}$ & Pre-test Scores \\
\hline Mean & 85.9067 & 27.2267 \\
\hline Variance & 65.6715 & 117.5 \\
\hline Observations & 25 & 25 \\
\hline Hypothesized Mean Difference & 0 & \\
\hline Df & 48 & \\
\hline T Stat & 16.2416 & \\
\hline T Critical two-tail & 2.0301 & \\
\hline
\end{tabular}

While this result was anticipated (in fact, this author would have been very dismayed if the class had failed to demonstrate that they had learned a great deal during the units!) it is mentioned here because the amount of improvement seemed to have a surprising psychological impact on the class. Although the students' graded pre-test scores were simply returned to them with no further mention made of the event, the students seemed very interested in seeing "how much they had learned." Several times, immediately after a class in which a post-test had been returned, students stopped by to indicate how much knowledge they had gained from pre-test to post-test. They seemed to be motivated by the fact that they were "getting something" out of the class.

\section{Qualitative Input from the Pre-test Class}

In addition to the data analysis above, I sought anonymous written qualitative feedback from the Pre-test class at the semester's end regarding their feelings about the usefulness and appropriateness of the pre-tests. While most responses simply indicated, "It was helpful," or "I liked it," several students provided more comprehensive responses. The unedited comments of these students follow in Table 8. It is noteworthy that there were no negative comments received regarding pre-testing. This was especially interesting, because when the first pre-test was administered at the beginning of the semester, there were grumbles from the students regarding "what a waste of time this is" and "why on earth are we doing this?" This being the case, it was anticipated that at least some students would indicate negative feelings toward the pre-testing experience. However, whatever misgivings were felt initially had apparently been mitigated by the semester's end. 
Table 8

Student Comments Regarding Pre-tests

I believe that the pretests really helped with the class. It helped to show the information that you thought was important and the type of questions that might be on the test. It didn't make the class very easy though, because you changed the questions and added some as well.

The pretests were good. They did make it almost too easy for the first test, but the rest were fine. Overall, I'd say they helped a great deal.

I thought that the pre-tests helped a lot. They made it easier for me to study, and gave me some insight on what to expect for the next test so I could be better prepared for it.

I felt that the pre-test were very helpful. It not only made the tests easier to study for, but it also helped me learn the important information. I will probably remember the stuff I learned in your class twice as long as I would any other something that I learned in college.

As far as the pre-test goes, I found them very beneficial. At times the material seemed spoon fed. However, I have my private pilots license and have been working at an FBO for 5 years; thus, the material was mostly review to me.

I thought the pretests were a good idea because you didn't tell us how similar the actual tests would or would not be to them. Sometimes they were similar and other times they were very different, and I thought that was helpful. I definitely used them to study, and they helped me a lot.

\section{Discussion}

It was clear from the analysis of data that there was a significant difference between the Learning Objectives class and the Pre-test class in their performance on each of the unit tests. The difference was most significant on the second test, followed by the first test, and then the third. On the third test, the computed t-statistic value was just above the critical t-value, indicating that the pre-testing was not as significant a factor on this test as it was on the first two tests. It could be hypothesized that by that point, late in the semester, students were becoming accustomed to the expectations of their preparation for the course tests. The final exam scores for the Pre-test class were also significantly better than the Learning Objective class, pointing towards the possibility that the students were not only better prepared for the initial unit tests over a topic, but that the knowledge stayed with them for a longer time.

Of course, the possibility arises that perhaps the Pre-test class just happened to be a stronger group of students than the Learning Objectives class. Since pretesting both groups at the start of the semester would have defeated the purpose of the study, it was not possible to ascertain that the groups were not significantly different at the start of the study by this usual method. Instead, the cumulative college GPA's of the students in each class were examined at the end of the semester, and a two sample t-test was performed to determine if there was a significant difference between these GPA's. The Pre-testing class did not turn out to have a significantly different cumulative GPA than the Learning Objectives class $(t(55)=.6732$, $p<0.05$ ), so seemingly the effect of the pre-testing was the primary influencing factor in the difference in performance on the course tests. In retrospect, this check of possible significant difference in GPA probably should have been done at the start of the semester, as the entire effort would have been in vain had there turned out to be a significant difference. However, for a significant number of the students, this class was taken during their first semester at MTSU, and so no college GPA information would have been available at the beginning of the semester.

In addition to the significant difference in overall test performance that was found, the qualitative comments of the students indicate that they thought the pre-testing methodology was positive. The fact that students could easily see how much more they knew at the end of each unit, versus what they knew at the beginning of the unit, proved to be very motivating. The Pre-test class seemed to develop a positive momentum and morale, simply based on 
how much everyone was measurably learning. While the other class was being taught in exactly the same method, just without the unit pre-tests, they did not seem as aware of how much they were learning. This particular factor had not been thought of as an influence, but it seemed that it was.

\section{Conclusions}

It is somewhat unclear why the simple act of taking a pre-test was so impactive on student performance on the subsequent unit post-test. The test questions were taken directly from the learning objectives that had been developed for the course, and the students that were not pretested were provided with these learning objectives. In addition to being provided these objectives, students were encouraged to track their progress through the unit by referencing these specific objectives. Even given this fact, the students who took the pre-tests seemed to have a better grasp of the objectives of each unit. Perhaps the physical act of taking a test impressed upon students more clearly the expectations than simply reading a list of objectives. Since taking a pre-test involves active instead of passive learning, the impact seems to have been greater for the students involved.

The largest identified problem with conducting a class in this manner is that the instructor has to be very clear of their objectives at the outset of each unit. Since the specific learning objectives for this course had already been developed, it was not too difficult to develop pre-test assessment items from these objectives. Had the objectives not existed, it would have been impossible to develop appropriate assessment items without first developing the learning objectives.

Another difficulty is developing numerous highquality test questions on a specific topic. For example, just how many ways can an instructor possibly ask, "What is the angle between the chord line and the relative wind called?" Since different questions need to be used on the pre-tests and post-tests, a large bank of questions must be developed.
This is somewhat more difficult and time consuming than just having to create the usual post-test assessments.

A small concern at the beginning of the semester was the amount of class time it would take to conduct the pre-tests. In reality, most students did not know enough about the topics to spend much time working on the pretests (there were a lot of items left blank). The small amount of class time it took to execute the pre-tests was well spent when the subsequent student performance was considered. Learning was taking place in the pre-test situation; it was just a different type of learning than customarily experienced.

The only other identified disadvantage of pretesting is that there probably is not as much "peripheral" learning occurring as there is in classes without pre-testing. There are obviously any number of topics that do not rank as "most important" to an instructor, but that may in fact be an area of interest to a particular student. Had students not been given a pre-test (or even the list of learning objectives for that matter) and therefore realized the instructor did not consider a particular area important, a student may have investigated a topic of interest to them in more depth. Ultimately, at this level (freshman) class, it seems appropriate for students to concentrate on the areas that an instructor has determined are most important. At upper class or higher levels of coursework, this approach does not seem as beneficial, as students need to learn to investigate and learn more independently.

Finally, it should be noted that this study was obviously very small and specific to this course, and should be replicated to determine if the effect was genuine and repeatable. With that said, all indications from this study are that for this type and level of class, pre-testing provides an effective means of communicating to students what the objectives of the course are. This clarity of expectations seemed to be helpful to students in mastering the knowledge and skills required to be successful in the course. 7

Wendy S. Beckman is an Associate Professor in the Aerospace Department at Middle Tennessee State University. She holds a Bachelor of Science degree from North Carolina State University, a Master of Science degree from the University of Missouri - Rolla, and a Doctorate in Higher Education Administration from Saint Louis University. She also holds Airline Transport Pilot and Certified Flight Instructor (CFII, MEI) certificates. 


\section{References}

Angelo, T., \& Cross, K. (1993). Classroom Assessment Techniques: A Handbook for College Teachers (2 ${ }^{\text {nd }}$ ed.). San Francisco: Jossey-Bass.

Bernauer, J.A. (1998). Teaching for measurable outcomes. Journal on Excellence in College Teaching, 9(2), 25-46.

Liggitt-Fox, D. (1997, February). Fighting student misconceptions: three effective strategies. Science Scope, 28-30.

Linn, R.L. \& Miller, M.D. (2005). Measurement and Assessment in Teaching ( $9^{\text {th }}$ ed.). New Jersey: Pearson.

Ochs, R.S. (1998). The first-day quiz as a teaching technique. Journal of Chemical Education, 75(4), 401-404.

Resnick, L.B., \& Resnick, D.P. (1992). Assessing the thinking curriculum: New tools for educational reform. In B.R. Gifford \& M.C. O'Connor (Eds.), Changing Assessments: Alternative Views of Aptitude, Achievement, and Instruction (pp. 37-75). Boston: Kluwer.

Shepard, L.A. (2001). The role of classroom assessment in teaching and learning. In V. Richardson (Ed.) Handbook of Research on Teaching ( $4^{\text {th }}$ ed.), (pp. 1066-1101). Washington, D.C.: American Educational Research Association.

Stiggins, R.J. (1994). Student Centered Classroom Assessment. New York: Macmillan.

Vocational Instructional Materials Lab. (1998). Applied Mathematics: Targets for Learning Strategies for Preparing Successful Problem Solvers in the Workplace (pp. 36-40). Columbus: Ohio State University. 